\title{
The Alteration Barrier in "Artificial Geothermal System" around a Repository of High-Level Radioactive Waste
}

\author{
Hiroshi TAKAHASHI*
}

\begin{abstract}
Key words : 高レベル放射性廃棄物 high level radioactive waste, 変質帯バリア alteration barrier, 人エバリア engineered barrier, 天然バリア natural barrier
\end{abstract}

\begin{abstract}
The multibarrier system for deep geologic disposal of high-level, long-lived and heat generating radioactive waste has been devised in order to keep them away from humanbeing. This system consists of engineering barrier and geological natural barrier. After burying the waste, an "artificial geothermal system" may be constructed because of heat from radioactive waste, and the artificial geothermal system would make some hydrothermal minerals and alteration zone, in host rocks.

Hosokura ore deposits were made by an "old geothermal system", and have impermeable zones developed along some ore veins. In some active geothermal area in Japan, geothermal alteration zones seem to play as caprocks. That is, a part of geothermal alteration zones sometimes work as hydraulic barrier (alteration barrier), which is very important for hydrology of that area. In this paper, the possibility about formation of the "artificial alteration zone" at geologic disposal is considered.

Smectite, $\alpha$-cristobalite, clinoptilolite, mordenite and stilbite are possibly formed by the interaction between neutral hot water and volcanic glass at temperatures below $100^{\circ} \mathrm{C}$ in an artificial geothermal system. These minerals have high adsorption capacity of radionuclides and low permeability. Because of these properties, the alterative minerals may form an "alteration barrier" which supports the multibarrier system.

Nowadays, a large amount of bentonite is necessary for buffer and backfill material. Mixing volcanic glasses with bentonite may reduce the amount of bentonite, because volcanic glasses may change to smectite and form a part of alteration barrier in a long time.
\end{abstract}

\section{1. は じめに}

現在, 原子力発電に伴う放射性廃棄物が重大な社会問 題になりつつある。このため, 高レベル放射性廃棄物を 地下数百 $\mathrm{m}$ に埋設する地層処分計画が進んでいる1。
埋設後, 高レベル放射性廃棄物は崩壊し発熱するため, 放射性廃棄物処分場には低温の『人工地熱系』が発生

\footnotetext{
* 大手開発侏 地款熱開発部 Bishimetal Exploration Co., Ltd., Geothermal Dept.
} 
し，そこに変質作用が生じることが予想される。

『化石地熱系』である細倉鉱床では, 鉱脈周辺に熱水 変質により不透水帯が形成されている2)。また, 『活地 熱系』の調査・開発では不透水性の岩石であるキャップ ロックの存在が重要視されている。キャップロックは初 生的な岩相に由来するものだけでなく, 2 次的な熱水変 質によっても形成される3)。多くの活地熱系では不透水 性の熱水変質帯がキャップロックの役割を果している4)。 このように, 地熱系の変質帯の一部は水理構造を規制す る水理学的バリアの機能を有している場合がある。本論 文では, 変質作用により形成された不透水帯（水理学的 バリア）を変質帯バリアと呼ぶことにする。

千木良 ${ }^{5)}$ は, 活地熱系での現象をヒントに「高温の放 射性廃棄物処分場から低温の周辺域へ熱水が流動するこ とを想定し，熱水からのシリカ鉱物の沈殿により周辺岩 石のフラクチャーを充填をするシステム」の研究を行っ ている。

本論文では，細倉鉱床，化石地熱系，活地熱系の変質 帯の産状をもとに，高レベル放射性廃棄物処分場に予想 される变質作用と変質帯バリアについて考察する。

\section{2. 高レベル放射性廃棄物処分場の人工地熱系}

\section{1 高レベル放射性廃棄物処分場}

高レベル放射性廃棄物を地下深部の地層中に処分し， 将来にわたって人間とその生活環境から安全に隔離する ことが地層処分の考え方である。高レベル放射性廃棄物 処分場（以下，処分場とする）は地上施設之地下施設か ら成り，地下施設へのアクセスは立坑・斜坑・スパイラ 儿坑などが考えられている。地下施設には処分坑道が掘 削され，廃棄物体の定置方式は坑道横置方式，処分孔縦 置方式がある6)(図-1)。処分後は周辺の地層（後記の 天然バリア）の本来の性能を保持するため, 地下施設を 閉鎖する必要がある。坑道を閉鎖する埋め戻し材には， 低透水性, 長期健全性が要求され, ベントナイト（スメ クタイトを主成分とする粘土)などが検討されている6)。

地層処分では地下水の影響, 地殼変動を考慮する必要 がある。放射性核種が地下水に溶解し人間環境に運ばれ る可能性もある。また, 地殼の大規模な変動により人間 環境に近づくことも考えられる7)。このため, 高レベル 廃棄物を安全に隔離する多重バリアシステムが考案され ている。このシステムは工学的な多重の防護（人エバリ ア）, 地質学的な環境による防護（天然バリア）からな $3^{1), 7)}($ 図 -1$)$ 。

人工バリアはガラス固化体，オーバーパック，緩衝材 から構築される1),7)。ガラス固化体とオーバーパックを
含めて廃棄物体と呼ばれている。高レベル放射性廃棄物 はガラス固化され，キャニスター（ステンレス鋼製の容 器）に封入される。オーバーパックはキャニスターに入 ったガラス固化体を覆うもので，地圧等の外圧からガラ 固化体を保護する容器である。緩衝材には地下水の遮 断が期待され，廃棄物体を地圧や熱の集中から守ること も要求される。候補材料としては, 止水性・自己シール 性・核種吸着性などからベントナイトが有力である1),8)。

天然バリアは, 人工バリアを取り巻く地下深部の地層 とそこに含まれる物質の総称である。天然バリアとなり うる地層には, 地表に比べてはるかに外的要因による影 響を受けにくく，極めて長期にわたって安定であるこ と, 地下水の移動が緩慢であることが要求される11,7)。

\section{2 人工地熱系の発生}

\section{（1）人工地熱系の熱源}

処分坑道周辺には埋設後に高レベル放射性廃棄物から 崩壊熱が放出され，廃棄物体を熱源とする低温の地熱系 が発生する。廃棄物体の埋設密度により人工地熱系の温 度をコントロールできる。緩衝材の有力材料であるスメ クタイトがイライトに变質すると, 緩衝材の性能が劣化 するとこが懸念される8)。このため, 廃棄物体を取り囲 む緩衝材の埋設後の温度を $100^{\circ} \mathrm{C}$ 以下にするように計画 している6)。

石川ほか99) は処分坑道（梁度 $1,000 \mathrm{~m}$ ）の初期温度を $45^{\circ} \mathrm{C}$ と仮定し, 3 ケースの廃棄物体の埋設密度で埋設後 の緩衝材の温度変化をシミュレーションしている。石川 ほが9 に従って，緩衝材内側（オーバーパックとの境界

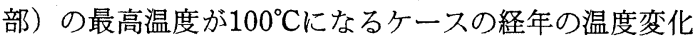
の例を以下に示す。

・初期温度 $; 45^{\circ} \mathrm{C} \cdot 1$ 年後 $; 80^{\circ} \mathrm{C}$

- 20 年後 $; 100^{\circ} \mathrm{C} \quad \cdot 100$ 年後 $; 90^{\circ} \mathrm{C}$

$\cdot 1000$ 年後 $; 60^{\circ} \mathrm{C} \quad \cdot 10000$ 年後 ; $50^{\circ} \mathrm{C}$

人工地熱系の温度は数十年で最高温度の $100^{\circ} \mathrm{C}$ とな り，その後徐々に低下し， 1 万年後には $50^{\circ} \mathrm{C}$ 程度になる と推定される。

\section{（2）人工地熱系の熱水性状}

処分場は建設時には地下水が一旦不飽和状態となる が, 埋設後再び深部地下水で飽和される再冠水が起こ る。周辺のこの深部地下水が廃棄物体からの放熱により 加熱され，人工地熱系を満たす熱水となる。

多くの活地熱系では深部熱水は中性を示すが，酸性の 深部熱水がしばしば確認されている。その成因としては 硫黄鉱床の変質, $\mathrm{H}_{2} \mathrm{~S}$ ガス, $\mathrm{SO}_{2}$ ガスの地下水への混 入が挙げられる ${ }^{10)}$ 。硫黄鉱床の変質は中性熱水と岩石 中の硫黄の酸化還元反応によって生成されたと考えら 


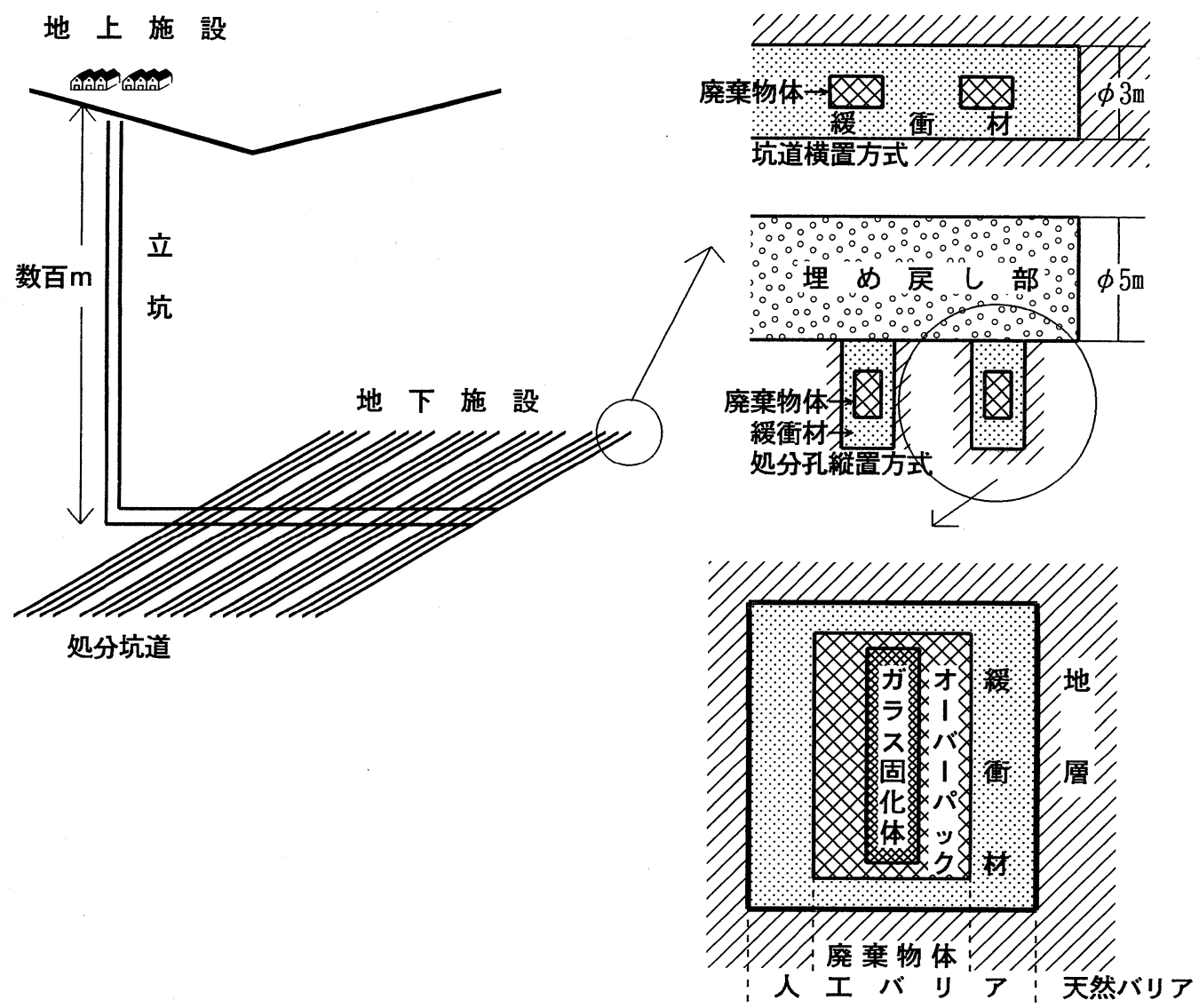

多重バリアシステム

図-1 放射性廃棄物処分場の概念図

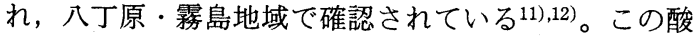
性熱水は中性変質帯内に局所的に存在し，近傍には中性 熱水が貯留されている場合が多い11)。また, 深部熱水 の沸騰により放出される $\mathrm{H}_{2} \mathrm{~S}$ ガスの地下水への混入, およびマグマ性の $\mathrm{SO}_{2}$ ガスの地下水への混入により大 量の酸性熱水が生成されることがある。

処分坑道の掘削により地下に酸素が供給されると, 黄 鉄鉱の酸化による酸性水の生成も考えられるが ${ }^{13)}$ ，処 分場には火山活動がなく, 黄鉄鉱が大量に存在しない地 域が選定されるため, 人工地熱系の熱水性状は中性と想 定される。

\section{3. 人工地熱系の変質作用}

\section{1 細倉鉱床周辺の広域変質作用の実例}

人工地熱系で想定される低温の中性熱水環境下の変質 作用は，細倉釷床周辺の広域変質帯で観察できる。
（1）細倉鉱床周辺の地質

細倉鉱床は宮城県北部にある熱水性鉱脈型の鉛・亜鉛 鉱床である（図-2）。鉱床は東北グリンタフ地域に位 置し, 鉱床周辺の地質は新第三系中新統, 鮮新統〜更新 統加なる(図-3)。

下・中部中新統（細倉層）は鉱床域（鉱脈分布域）に 広く分布し，主要な鉱床母岩となっている。岩相は安山 岩溶岩・年碎岩・凝灰質泥岩加成る。その上位には不 整合で，中部中新統(花山層)が鉱床域周辺に分布する。 岩相は軽石凝灰岩・安山岩溶岩・凝灰質砂岩加成る。 それらに不整合に上部中新統（文字層）が分布し，岩相 は軽石凝灰岩・シルト岩・デイサイト溶岩から成る。さ らに鮮新統～更新統（北川層）が鉱床域外に広く分布す る。岩相はデイサイト質溶結凝灭岩・軽石凝灭岩から成 る火砕流堆積物である14),15)。 


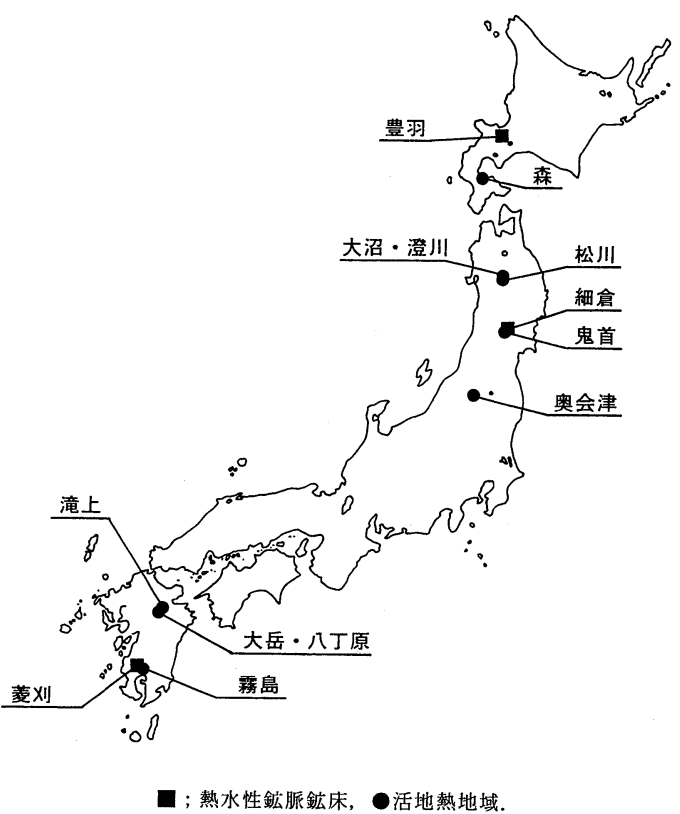

図-2 化石・活地熱系の位置図

\section{（2）広域変質帯の变質分帯}

細倉鉱床周辺の広域変質は, 肉眼では下位の地層ほど 緑色化变質が強くなっている。各層準から採取した岩石 のX線分析, 顕微鏡による薄片観察をもとにした変質 鉱物の組合わせにより, 広域変質帯を火山ガラス帯, $\alpha$ クリストバライト帯, スメクタイト帯, 緑泥石帯に分帯 した (図-4)。

\section{1）火山ガラス帯}

肉眼では新鮮で，顕微鏡下でも火山ガラスに变質が認 められない未変質帯である。火山ガラス帯に属する層準 は鮮新統〜更新統の一部である。

2） $\alpha$ クリスドライト帯

肉眼では新鮮で, 顕微鏡下では火山ガラスの一部が $\alpha$ クリストバライトに変質している。 $\alpha$ クリストバライ ト帯に属する層準は鮮新統〜更新統の一部，上部中新統 である。

\section{3）スメクタイト帯}

肉眼では弱い緑色化恋質が認められ，顕微鏡下では変 質鉱物としてスメクタイト・ $\alpha$ リストバライトが生 じ，モルデン沸石・斜プチロル沸石をしばしば伴う。ス メクタイトは火山ガラスを交代し, 角閃石類・輝石類の 結晶表面に認められることもある。 ・沸石鉱物は火山ガラスを交代しているほか，空隙に も晶出している。スメクタイト帯に属する層準は中部中

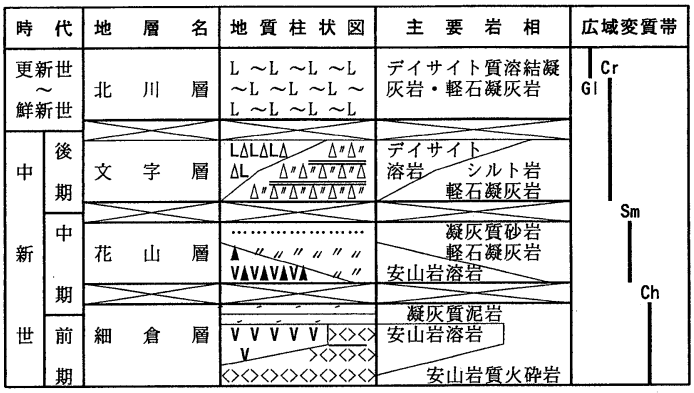

広域変質帯の变質分帯 : G1; 火山ガラス帯, $\mathrm{Cr} ; \alpha$ クリストバライト帯, $\mathrm{Sm}$; スメクタイト帯, Ch; 緑泥石帯.

\section{図-3 細倉鉱床周边の模式地質柱状図}

\begin{tabular}{|c|c|c|c|c|c|}
\hline 变留鋝物 & 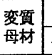 & 火山ガラス带 & 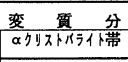 & スメクタイト帯 & 稰泥石带 \\
\hline 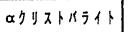 & G1 1 & & & & \\
\hline 2 次石英 & G1 & & & & \\
\hline スメクタイト & $\begin{array}{ll}\mathrm{G} & \mathrm{I} \\
\mathrm{Mm} & \end{array}$ & & & & \\
\hline 粶 泥 石 & $\begin{array}{ll}\mathrm{G} 1 \\
\mathrm{Mm}\end{array}$ & & & & \\
\hline セリサイト & $\begin{array}{lll}\begin{array}{c}G \\
\mathrm{P}\end{array} & 1 \\
\end{array}$ & & & & \\
\hline モルテンン沸石 & G1 & & & …... & \\
\hline 針プチロル沸石 & G1 & & & $\cdots$ & \\
\hline 方解石 & $\begin{array}{ll}\mathrm{G} 1 \\
\mathrm{Mm} \\
\mathrm{P} 1\end{array}$ & & & & \\
\hline アルパイト & $\begin{array}{lll}G & 1 \\
P & 1\end{array}$ & & & & \\
\hline
\end{tabular}

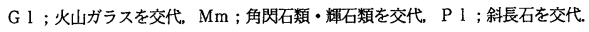

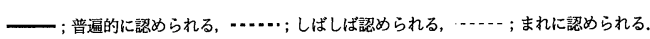

図-4 細倉鉱床周辺の広域変質帯の変質鉱物組合せ

新統である。

4）緑泥石帯

肉眼では緑色化变質が顕著で, 顕微鏡下では火山ガラ ス, 角閃石類・輝石類・斜長石の結晶に変質が認められ る。变質鉱物は緑泥石・アルバイト・石英・方解石から 成り, スメクタイトを伴うこともある。緑泥石帯に属す る層準は下・中部中新統である。

\section{（3）広域変質帯の特徵}

顕微鏡による薄片観察から，火山ガラスが最も变質に 弱い物質であることがわかる。鉱物の変質しやすさは， 角閃石類・輝石類 $>$ 斜長石 $>$ 石英の順である。また， 斑晶よりも石基の鉱物の方がより変質を受けている。

広域变質作用には層準規制が認められ，代表的な変質 鉱物は上位層より下位層に向かって, 火山ガラス $\rightarrow \alpha$ クリストバライト $\rightarrow$ スメタイト・低温型沸石鉱物 $\rightarrow$ 緑泥石となる（図-3）。このように，上位層から下位 層に向かってより高温の変質鉱物が生成されている。こ 
の広域変質作用は局所的な熱水活動によるものではな

く，続成作用と考えられる。

\section{2 人工地熱系に予想される変質鉱物}

$50 \sim 100^{\circ} \mathrm{C}$ の中性熱水環境下の人工地熱系で生成され る変質鉱物は, 油田地域の続成作用, 活地熱地域の熱水 変質作用を参考に予想できる（図-5)。我が国の油田 地域では凝灰岩が多く存在し, 火山ガラスが続成作用で スメクタイト・斜プチロル沸石などに変質している。火 山ガラスのスメクタイトへの転換温度は50 $\mathrm{C}$ 以下, 斜 プチロル沸石への転換温度は䄪 $55^{\circ} \mathrm{C}$ と推定される ${ }^{16)}$ 。 森ほか ${ }^{17)}$, HENLY et al. ${ }^{18)}$ は活地熱地域での変質鉱物 の安定温度を示しているが， $50 \sim 100^{\circ} \mathrm{C} て ゙$ 安定な変質鉱 物は油田地域の続成作用で生成される鉱物之同様であ る。これらのデータをもとにすると，細倉鉱床周辺の広 域変質帯のスメクタイト帯は50〜 $100^{\circ} \mathrm{C}$ で生成されたと 推定される。

黒曜石（流紋岩質〜デイサイト質火山ガラス）と純水 による閉鎖系 $100^{\circ} \mathrm{C}$ 水熱反応では，90日以降に黒曜石 の表面にスメクタイトの生成（部分変質）が確認されて いる19)。この実験から火山ガラスが $100^{\circ} \mathrm{C}$ 程度の低温熱 水との反応により短時間でスメクタイトに部分変質する ことがわかる。

細倉鉱床周辺のスメクタイト帯の被変質岩はデイサイ 卜質〜安山岩質火山岩類である。流紋岩質・デイサイト 質・安山岩質火山岩類では変質鉱物種は同様であるが, 玄武岩質の場合は前記のものに加えてシリカに乏しい沸 石鉱物（束沸石）が出現することが知られている20)。

これらのことから，火山ガラスを大量に含む人工地熱 系では火山ガラスを母材に以下の変質鉱物の生成が予想 される。

(1)スメクタイト, (2) $\alpha$ クリスバライト, (3)斜 プチロル沸石，(4)モルデン沸石，(5)束沸石（玄武岩 質火山ガラスの場合)

\begin{tabular}{|c|c|c|c|c|}
\hline 変 質 鉱 物 & 出典 & & 安 定 温 度 & \\
\hline スメクタイト & $\begin{array}{l}* 1 \\
* 2\end{array}$ & 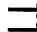 & & \\
\hline モルテン沸石 & $\begin{array}{l}* 1 \\
* 2\end{array}$ & & & \\
\hline 鈄プチロル沸石 & $\begin{array}{l}* 1 \\
* 2\end{array}$ & & & \\
\hline 束 沸 石 & $* 1$ & & & \\
\hline 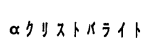 & $\begin{array}{l}* 1 \\
* 2\end{array}$ & I & & \\
\hline
\end{tabular}

図-5 50 $100^{\circ} \mathrm{C}$ C゙安定な変澌鉱物 (出典 $* 1$; 青柳ほか(1979). ＊2; 森ほか(1980).)

\section{4. 人工地熱系の変質帯バリア}

\section{1 細倉鉱床の変質帯バリアの実例}

（1）細倉鉱床中央部の地質・鉱床

細倉鉱床は化石地熱系で，鉱床生成年代は中新世後期 と推定される ${ }^{21)}$ 。本論文では鉱床中央部の主要鉱脈で ある富士本脈の熱水変質帯を紹介する。鉱脈は正断層性 の断層・裂罅に形成されているもので, 硫化鉱物, 石 英，セリサイトなどの粘土鉱物で充填されている。ま た，鉙脈周辺には断層運動に伴う断層角磁帯（碟径 10〜 $50 \mathrm{~cm} ）$ が発達し，剪断面にはしばしば鏡肌が認め られる。

富士本脈周辺の地質は, 細倉層の安山岩溶岩・火砕岩 から成る（図-6）。溶岩は浅部レベルに分布し，節理

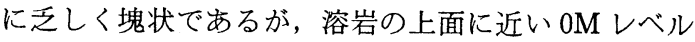
の鉱脈上盤側には自破砕質角磁帯が分布する。自破砕質 角䃯帯は礫径 $10 \sim 20 \mathrm{~cm}$ 程度の凝灰角踏岩様の岩相を 示し, 溶岩流の冷却・流動によってその上面に形成され たものと考えられる。火砕岩は深部レベルに分布し，凝

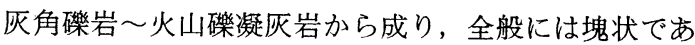
る。

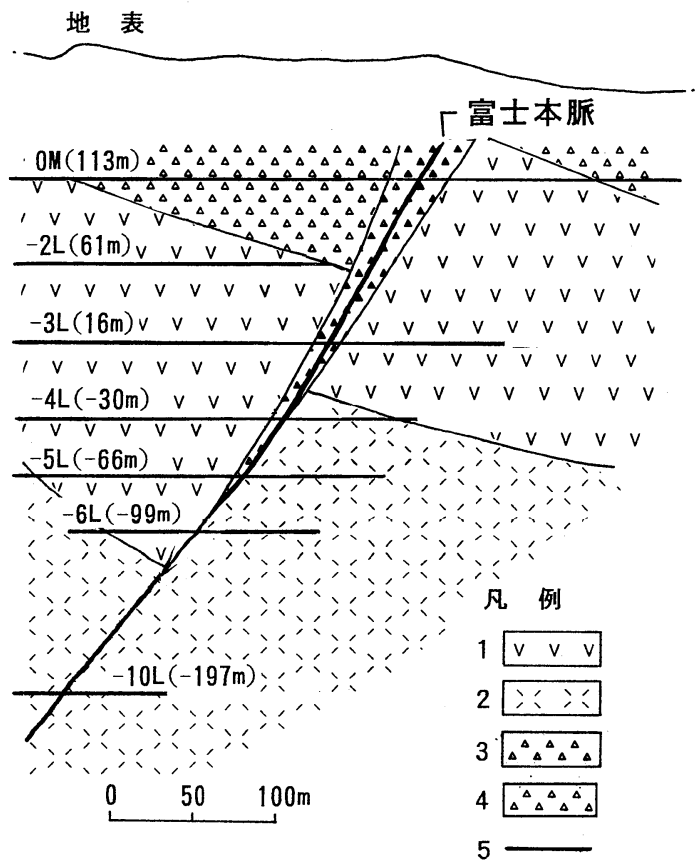

1. 安山岩溶岩, 2. 安山岩質火砕岩, 3. 断層角踏帯, 4. 自破砕質角碟帯，5. 坑道レベル. 図-6 富士本脈周辺の地犋断面図 


\section{（2）熱水変質帯の変質分帯}

鉱床母岩は緑泥石帯に属する広域変質作用を受け，鉱 脈周辺ではその後の鉱化作用を伴う熱水変質を受けてい る15)。鉱脈周辺で採取した熱水変質岩の X 線分析, 薄 片観察をもとに, 釷脈際よりカリウム質変質帯, 粘土化 変質帯, 弱変質帯に分帯した (図-7)。これらの熱水 変質帯はカリ長石・セリサイト・スメクタイトで特徴づ けられ, 歌田 ${ }^{20)}$ の中性变質帯に当たる。

\section{1） カリウム質変質帯}

変質鉱物は鉱脈の構成物と類似し, 石英 - カリ長石 ・セリサイト・セリサイト/スメクタイト混合層鉱物 （以下，混合層鉱物とする）加成る。カリウム質変質 帯は鉱脈際に分布し，-5L レベルからー3L レベル間で は強い珪化が認められる。

2）粘土化変質帯

変質鉱物は混合層鉱物・スメクタイトから成る。粘土 化変質帯はカリウム質変質帯の外側に分布し, $0 \mathrm{M} レ$ レ゙ ルの鉱脈上盤側に広く分布する。

3）弱変質帯

変質鉱物は広域変質帯（緑泥石帯）と類似するが, 少 量の混合層鉱物を伴う。弱変質帯は粘土化変質帯の外側 に分布する。

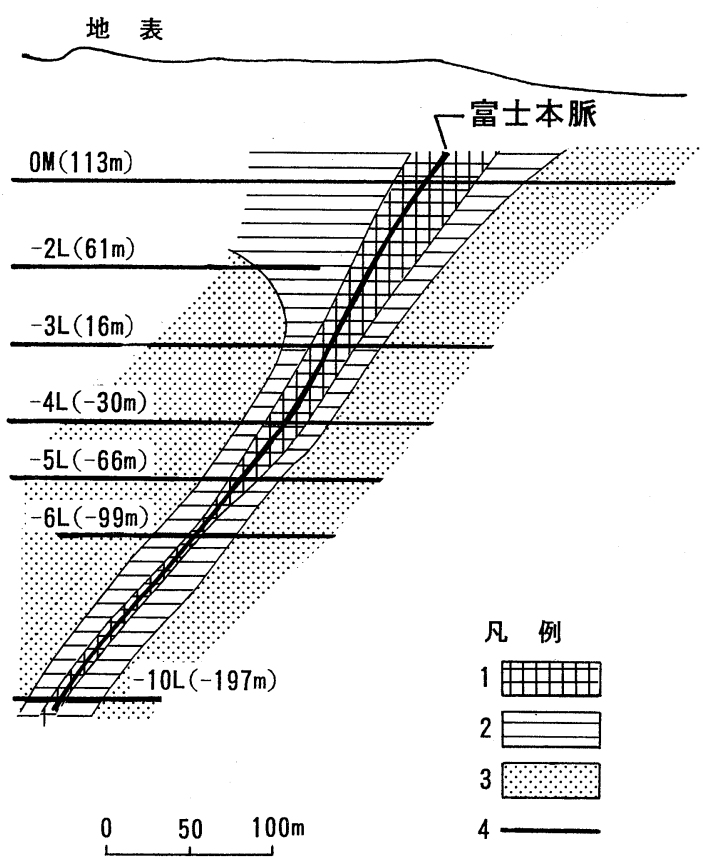

1. カリウム質変質帯、2. 粘土化変質帯, 3. 弱変質帯, 4. 坑道レベル. 図 -7 富士本脈周辺の熱水変質分帯図

\section{（3）鉱脈周辺の水理構造}

カリウム質変質帯と粘土化変質帯の幅とその母岩の岩 相を表ー1に示す。カリウム質変質帯は主に断層角唩帯 に分布し, 鉱脈際の安山岩溶岩・火砕岩にも小規模に認 められる。粘土化変質帯は $0 \mathrm{M} レ$ レ゙ルの鉱脈上盤側の 自破砕質角碟帯に層状に広がる。安山岩溶岩・火砕岩の 粘土化変質帯の幅は10 20 m である。

変質帯の幅を規制するパラメーターは作用する熱水の 流速 (主に透水性) - 反応速度 (主に温度 $\cdot \mathrm{pH}) \cdot$ 接触 面積などであるが, 流速が最も重要なパラメーターであ る ${ }^{22)}$ 。岩石の透水性はフラクチャーの発達状態に支配 され，断層角礫帯は一-3オーダー（透水係数をオーダー で表現する；例として，10 $10^{-3} \mathrm{~cm} / \mathrm{s}$ はー3オーダー）程 度, 自破砕質溶岩にはー2オーダー程度の透水性を有し ているものもある ${ }^{23)}$ 。細倉鉱床の熱水活動初期の岩石 の透水性を推定すると, 断層・裂罅 (その後の鉱脈), 断層角磁帯, 自破砕質角礫帯は透水性が良好で, 一方, 安山岩溶岩・火碎岩は透水性は不良であったと考えられ る。

\section{（4）変質帯バリアの形成}

細倉鉱床周辺では中新世後期に熱源が発生し地熱系が 形成された。地表より漫透した天水が地下深部の熱源に より加熱され, 中性の深部熱水が生成された ${ }^{2)}$ 。深部熱 水はフラクチャ一帯（断層・裂罅, 断層角砅帯）を上昇 し，自破砕質角䃯帯に流動した。

熱水の流動により, 断層・裂罅は硫化鉱物・石英・粘 土鉱物により完全に充填され鉱脈となった。断層角碟帯 はカリウム質変質を受け網状脈（幅 $10 \mathrm{~mm}$ 以下）が発

表-1 富士本脈上盤側の熱水変質帯の幅と岩相の関係

\begin{tabular}{|c|c|c|}
\hline \multirow{2}{*}{ 坑道レベル } & 熱 水 変 & 質 帯 の 幅 \\
\hline & 扐邡質変質帯 & 粘土化変質帯 \\
\hline $0 \mathrm{M}$ & $\begin{array}{c}20 \mathrm{~m} \\
\text { (断層角磷帯) }\end{array}$ & $\begin{array}{c}85 \mathrm{~m} \text { 以上 } \\
\text { (自破砕質角砂帯) }\end{array}$ \\
\hline$-3 L$ & $\begin{array}{c}8 \mathrm{~m} \\
\text { (断層角礫帯) }\end{array}$ & $\begin{array}{c}14 \mathrm{~m} \\
\text { (安山岩溶岩) }\end{array}$ \\
\hline$-4 \mathrm{~L}$ & $\begin{array}{c}12 \mathrm{~m} \\
\text { (断層角啋帯) }\end{array}$ & $\begin{array}{c}13 \mathrm{~m} \\
\text { (安山岩溶岩) }\end{array}$ \\
\hline$-5 \mathrm{~L}$ & $\begin{array}{c}9 \mathrm{~m} \\
\text { (断層角䋶帯) }\end{array}$ & $\begin{array}{c}12 \mathrm{~m} \\
\text { (安山岩溶岩) }\end{array}$ \\
\hline$-6 \mathrm{~L}$ & $\begin{array}{c}1 \mathrm{~m} \\
\text { (安山岩溶岩) }\end{array}$ & $\begin{array}{c}6 \mathrm{~m} \\
\text { (安山岩溶岩) }\end{array}$ \\
\hline$-10 \mathrm{~L}$ & $\begin{array}{c}4 \mathrm{~m} \\
\text { (火 砕 岩) }\end{array}$ & $\begin{array}{c}13 \mathrm{~m} \\
\text { (火 砕 岩) }\end{array}$ \\
\hline
\end{tabular}


達し、フラクチャーは主に石英・カリ長石・粘土鉱物な どにより完全に充填されている。自破砕質角碩帯は安山 岩角磔の周囲が強い粘土化変質を受け磷間（幅10 mm 以下）は完全に粘土鉱物などにより充填されている。こ のように熱水活動の進行により, フラクチャーや空隙は 石英・粘土鉱物などによって充填され，透水性が低下し たと推定される。この傍証として, 鉱脈上盤側の $0 \mathrm{M}$ レベルの弱変質帯中では地下水が坑道天盤からしみ出し ているが，カリウム質変質帯・粘土化変質帯では天盤の 浸水は認められない。

また，フラクチャー帯（断層・裂罅, 断層角磷帯）に 接する塊状の安山岩溶岩・煠岩にもカリウム質変質帯 ・粘土化変質帯が認められる。溶岩にはをれに節理が 発達するが，節理は粘土鉱物などによって充填されてい る。火砕岩は基質が特に強い变質を受け, 地下水のし及 出しは認められない。

このように，熱水の流動により不透水性の変質帯バリ アがフラクチャー帯とその周囲に形成されたと推定され る(図-8)。

\section{2 化石地熱系の変質帯バリアの実例}

豊羽や菱刈などの熱水性鉣脈鉱床（化石地熱系）でも 変質帯バリアが存在する（図 -2 , 表 -2 )。

(1) 豊羽鋑床

豊羽鉱床は北海道札幌市にあり，新第三系に肧胎する 熱水性の鉱脈型銀・鉛・亜鉛鉱床である。主要鉱脈の上 位にはセリサイト・スメクタイト・カオリナイトから成 る粘土化変質帯が分布し ${ }^{24)}$, この粘土化変質帯が变質 帯バリアとなっている。

地 表
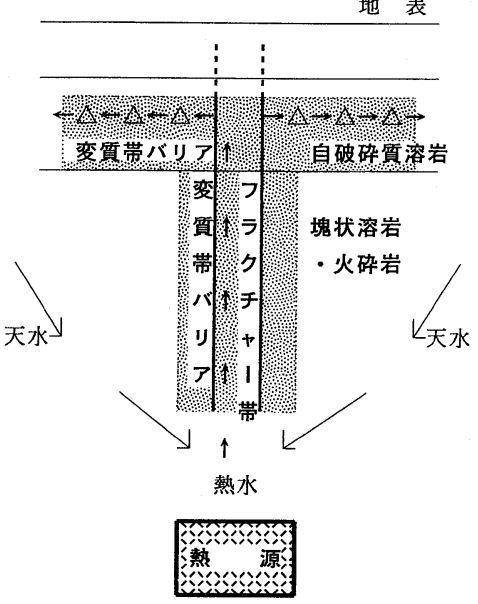

図-8 細倉鉱床における变質帯バリア形成の概念図
豊羽鉱床の一部は現在でも熱源が保持されている活地 熱地域で, 鉱脈の充填は完全ではなく熱水が存在し, 粘 土化変質帯の直下の鉱脈内では熱水の沸騰状態が確認さ れている24)。

\section{（2）菱刈鉱床}

菱刈鉱床は鹿児島県北部にある熱水性の鉱脈型金鉱床 である。鉙脈は先第三系の四万十累層群と第四紀の火山 岩類に肧胎し，主に四万十累層群中に発達する。

鉱脈は含金石英により充填され，鉱脈の直上の火山岩 類の角磁化帯がスメクタイト・混合層鉱物から成る強い 粘土化変質を受けいる ${ }^{25), 26)}$ 。含金石英脈・強粘土化変 質帯が変質帯バリアとなっている。

\section{3 活地熱系の変質帯バリア}

森, 大沼 - 澄川, 松川, 鬼首, 奥会津, 滝上, 大岳 ・八丁原, 霧島などの多くの活地熱系で变質帯バリア （变質帯キャップロック）の存在が報告されている（図 -2)。これらの変質帯バリアは浅層地下水層と深部の地 熱貯留層を分離している ${ }^{4}$ 。トリチウム $\left({ }^{3} \mathrm{H}\right)$ 濃度は, 浅層地下水（新しい水）の地熱貯留層中の地熱水（古い 水）への混合の目安となる。地熱水の ${ }^{3} \mathrm{H}$ 濃度が低い場 合は, 变質帯バリアが水理学的バリアとして機能してい ると解釈できる。

熱水変質帯は関与する熱水により, 中性変質帯・酸性 变質帯に区分できる。变質帯バリアを形成する中性変質 帯の变質鉱物はスメクタイトが主体で，その他はモルデ ン沸石・濁沸石・方解石である。酸性変質帯ではカオリ

\section{表 - 2 地熱系の变質帯バリアの特徴}

\begin{tabular}{|c|c|c|}
\hline 地 域 名 & $\begin{array}{l}\text { 変質帯バリア } \\
\text { の変質 鉱物 }\end{array}$ & $\begin{array}{lll}\text { 地 } & \text { 熱 } & \text { 系 } \\
\text { 種 } & & \text { 類 }\end{array}$ \\
\hline 細 & Smc, Mix, Qtz & 熱水性鉱床 \\
\hline 羽 & Ser, Smc, Kao & 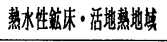 \\
\hline 刈 & Smc, Mix, Qtz & 熱水性鉱床 \\
\hline 森 & Smc & 活地熱地域 \\
\hline 大沼・澄川 & Smc & 活地熱地域 \\
\hline 川 & Pyr, Kao, Smc & 活地熱地域 \\
\hline 首 & Smc, Mrd, Lou & 活地熱地域 \\
\hline 奥 会 津 & Smc, Mrd, Ser & 活地熱地域 \\
\hline 上 & Kao, Pyr, Smc & 活地熱地域 \\
\hline 大岳・八丁原 & Pyr, Kao, Smc & 活地熱地域 \\
\hline 島 & Smc, Mrd, Cal & 活地熱地域 \\
\hline
\end{tabular}

Ser;セリサイト, Smc;スメクタイト, Mix; 混合層鉱物, Kao;カオリナイト, Pyr;パイロフィライト, Lou; 濁沸石, Mrd; モルテン沸石, $\mathrm{Cal}$;方解石, Qtz; 石英. 
ナイトとスメクタイトが主体をなしている（表－2）。

\section{（1）森地熱地域}

森地域は北海道南西部に位置し, 第四系が熱水変質を 受けている。この地域では多数の地熱井が掘削され，じ ょうご型カルデラの存在が確認されている。このカルデ ラの形成期は 1 万 2 千年前と推定され, カルデラ内は 1 度噴き上げられた爆発堆積物が火口近くに落下したカ ルデラ堆積物により埋められている27)。カルデラ堆積 物は周辺岩石の岩片と軽石から成り ${ }^{28)}$, 透水性は良好 であったと推定される。その後の熱水活動によってスメ クタイトなどの変質鉱物がカルデラ堆積物の一部に生成 され29), 現在はカルデラ堆積物の一部は変質帯バリア となっている。このことは，スメクタイトなどから成る 変質帯バリアが 1 万 2 千年以内で形成されていること を表している。高橋ほか30)のデータをもとにすると， 変質帯バリアは地温 $50 \sim 180^{\circ} \mathrm{C}$ 範囲に分布し, 厚さは 約 $400 \mathrm{~m}$ である。

（2）大沼・澄川地熱地域

大沼・澄川地域は秋田県北東部に位置する。この地域 では地熱貯留層の直上にスメクタイトなどから成る中性 変質帯が分布し ${ }^{31)}$, 変質帯バリアを形成している。窪 田 ${ }^{31)}$ のデータをもとにすると, 変質帯バリアは地温 $120 \sim 200^{\circ} \mathrm{C}$ 範囲に分布し，その厚さは約 $50 \sim 200 \mathrm{~m}$ である。変質帯バリア内では地熱井掘削中の循環泥水の 逸泥は少量である32)。

（3）松川地熱地域

松川地域は岩手県北西部に位置する。この地域ではパ イロフィライト・カオリナイト・スメクタイトなどから 成る酸性変質帯が地表下約 $700 \mathrm{~m}$ まで分布し ${ }^{33)}$, 変質

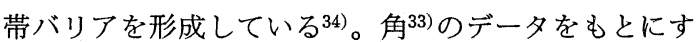
ると, 変質帯バリアは地温 $100 \sim 200^{\circ} \mathrm{C}$ 範囲に分布し, その厚さは約 $200 \mathrm{~m}$ と推定される。

（4）鬼首地熱地域

鬼首地域は宮城県北部に位置する。この地域では地熱 貯留層の直上にスメクタイト・モルデン沸石・濁沸石な どから成る中性変質帯が分布し ${ }^{35)}$, 変質帯バリアを形 成している可能性がある。高島 ${ }^{35)}$ のデータをもとにす ると, 変質帯バリアは地温 $50 \sim 150^{\circ} \mathrm{C}$ 範囲に分布し, その厚さは150〜300 m である。

（5）奥会津地熱地域

奥会津地域は福島県西部に位置する。この地域では地 熱貯留層の直上にスメクタイト・モルデン沸石などから 成る中性変質帯が变質帯バリアを形成している36)。 $\mathrm{SEKI}^{37)}$ のデータをもとにすると, 変質帯バリアは地温 $70 \sim 200^{\circ} \mathrm{C}$ 範囲に分布し，その厚さは約 $650 \mathrm{~m}$ であ
る。地熱水の ${ }^{3} \mathrm{H}$ 濃度は低い值を示す ${ }^{36) 。 ~}$

\section{（6）滝上地熱地域}

滝上地域は大分県南西部に位置する。この地域では力 オリナイト・パイロフィライト・スメクタイトなどから 成る酸性変質帯が変質帯バリアを形成している ${ }^{38)}$ 。変 質帯バリアは地温 $50 \sim 160^{\circ} \mathrm{C}$ 範囲に分布し， その厚さ は100 1,700 m である。地熱水の ${ }^{3} \mathrm{H}$ 濃度は低い值を 示す。

\section{（7）大岳・八丁原地熱地域}

大岳・八丁原地域は大分県南西部に位置する。この地 域では，パイロフィライト・カオリナイト・スメクタイ トなどから成る酸性変質帯が変質帯バリアを形成してい る39)。松本ほが40)・馬場ほか41)のデータをもとにする と, 変質帯バリアの分布域は地温 $80 \sim 200^{\circ} \mathrm{C}$ 範囲で, その厚さは約 $300 \sim 400 \mathrm{~m}$ である。地熱水の ${ }^{3} \mathrm{H}$ 濃度は 低い值を示す41)。

\section{（8）霧島地熱地域}

霧島地域は鹿児島県北部に位置する。この地域ではス メクタイト・モルデン沸石・方解石などの変質鉱物が節 理などのフラクチャーを充填し変質帯バリアを形成して いる ${ }^{42)}$ 。変質帯バリアは地温 $50 \sim 200^{\circ} \mathrm{C}$ 範囲に分布 し，その厚さは200～400 $\mathrm{m}$ である。地熱水の ${ }^{3} \mathrm{H}$ 濃度 は低い値を示す。

\section{4 人工地熱系に予想される変質帯バリア}

\section{（1）変質鉱物の特徵}

人工地熱系に火山ガラスが大量に含まれる場合，スメ クタイトなどの生成が予想される。予想される変質鉱物 の特倠を以下に示す。

1) スメクタイト

膨潤性・陽イオンの交換性を有する特異な性格を持つ 粘土鉱物である。その化学式は $\left(\mathrm{Na}_{2} \cdot \mathrm{K}_{2} \cdot \mathrm{Ca}\right)\left(\mathrm{Al}_{10}\right.$. $\left.\mathrm{Mg}_{2}\right) \mathrm{Si}_{24} \mathrm{O}_{60}(\mathrm{OH})_{12} \cdot n \mathrm{H}_{2} \mathrm{O}$ である。細倉鉱床周辺の広 域変質帯では火山ガラスを交代して存在する（図-4）。

油田地域ではスメクタイトがより高温で生成されるイ ライトに変化する際に放出される層間水が石油の移動の 営力になることが指摘され43),44)，スメクタイトには層 間水の吸着による保水の能力がある。スメクタイトの生 成によりその保水性による低透水性化が予想される。ま た，Csなどの陽イオンに対して優れた吸着特性を示 す45)。

2） $\alpha$ クリストバライト

シリカ鉱物で，化学式は $\mathrm{SiO}_{2}$ である。シリカ鉱物は 堆積岩のセメント物質となり，シリカ鉱物による交代が 進むと緻密堅硬となるのが珪化である。細倉鉱床周辺の 広域変質帯では $\alpha$ クリスドライトは火山ガラスを交 
代して存在するほか, 空隙にも晶出している（図一4）。

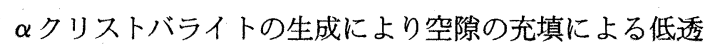
水性化が予想される。

3） モルデン沸石

沸石鉱物で, 化学式は $\left(\mathrm{Na}_{2} \cdot \mathrm{K}_{2} \cdot \mathrm{Ca}\right) \mathrm{Al}_{2} \mathrm{Si}_{10} \mathrm{O}_{24}$. $7 \mathrm{H}_{2} \mathrm{O}$ である。細倉鉱床周辺の広域変質帯では火山ガラ スを交代して存在するほか, 空隙にも晶出している（図 -4)。モルデン沸石の生成により空隙の充填による低透 水性化が予想される。また，Csなどの陽イオンに対し て優れた吸着特性を示す45)。

4) 斜プチロル沸石

沸石鉱物で, 化学式は $\left(\mathrm{Na}_{2} \cdot \mathrm{K}_{2} \cdot \mathrm{Ca}\right) \mathrm{Al}_{2} \mathrm{Si}_{7} \mathrm{O}_{18}$. $6 \mathrm{H}_{2} \mathrm{O}$ である。細倉鉱床周辺の広域変質帯では火山ガラ スを交代して存在するほか, 空隙にも晶出している（図 $-4)$ 。

油田地域では斜プチロル沸石がより高温で生成される 方沸石に変化する際に結晶水が放出されることが指摘さ れ46), 斜プチロル沸石には結晶水の吸着による保水の 能力がある。斜プチロル沸石の生成により，その保水性 および空隙の充填による低透水性化が予想される。また， Cs などの陽イオンに対して優れた吸着特性を示す45)。

5) 束沸石

沸石鉱物で, 化学式は $\left(\mathrm{Ca} \cdot \mathrm{Na}_{2} \cdot \mathrm{K}_{2}\right) \mathrm{Al}_{2} \mathrm{Si}_{7} \mathrm{O}_{18}$. $7 \mathrm{H}_{2} \mathrm{O}$ である。他の沸石鉣物同様に, 束沸石の生成によ り空隙の充填による低透水性化が予想される。

\section{(2) 変質バリア}

人工地熱系に予想される変質帯バリアの概念困を困一 9 に示す。

\section{1）人エバリア}

緩衝材として有力候補のベントナイトの人工地熱系で の変質に関しては, ナチュラルアナログ研究47)や变質 シミュレーション9)が行われている。これらの結果では, $100^{\circ} \mathrm{C}$ 程度の温度条件ではスメクタイトは安定で, 顕著 なイライト化は生じないと判断されている。

緩衝材はベントナイト単一材料のほか, 米国などでは
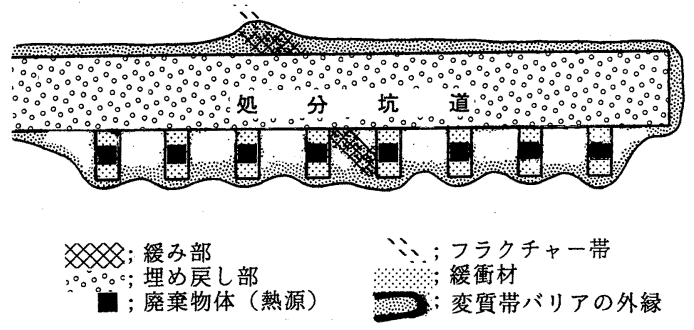

図-9人工地熱系における変質帯バリア形成の概念図
ベントナイトに沸石類・シリカなどの混合が検討されて いる45)。複合材料にもベントナイト単一材料同様に低 透水性（透水係数； -8 オーダー）であることが第一に 要求される。人工地熱系では火山ガラスの変質でスメク タイトなどが生成される可能性があることより，ベント ナイトと火山ガラスの複合材料の検討も興味深いと考え られる。

2）埋め戻し部

床次 ${ }^{48)}$ は，処分坑道などが水の通路とならないよう にする密封技術の重要性を指摘している。処分坑道を閉 鎖する埋め戻し材には，低透水性，核種吸着，長期健全 性が要求される。設計研究では埋め戻し部の透水係数を -5オーダーと仮定している6)。埋め戻し材としては, ベントナイト単一材料, およびベントナイトに珪砂・泥 岩岩片などを混合した複合材料が検討されている6)。

細倉鉱床の粘土化变質を受けた自破砕質角碰帯では, 砂径 $10 \mathrm{~cm}$ 程度の安山岩角礫の間隙を粘土釷物（混合層 鉱物・スメクタイト）が充填している。坑道掘削ずりを この角磁とみなすと，坑道掘削ずりの間隙に火山ガラス からスメクタイトを主とする変質鉱物を生成させると変 質帯バリアが形成される可能性がある（図一-10）。

国内のフィルダムの土質材料49)では, 粒径は50 mm 程度のものが $40 \sim 70 \%$ であるが，しゃ水性（透水係数； 一5オーダー程度）を確保するために，一般に粒径 $0.074 \mathrm{~mm}$ （200）以下の細粒材の含有比が一つの目安 にされ，10２0\%程度が適当とされている。フィルダ ムの材料データを参考に, 埋め戻し材の調整の一例を次 に示す。

・坑道掘削ズリ, 粒径 $50 \mathrm{~mm}$ 以下, 含有比約 $80 \%$ ・ベントナイト, 粒径 $0.074 \mathrm{~mm}$ 以下, 含有比約 $10 \%$ ・火山ガラス, 粒径 $0.074 \mathrm{~mm}$ 以下, 含有比約 $10 \%$ 火山ガラスとベントナイトの細粒材を $20 \%$ 程度とし， その他を坑道掘削ずりとする。
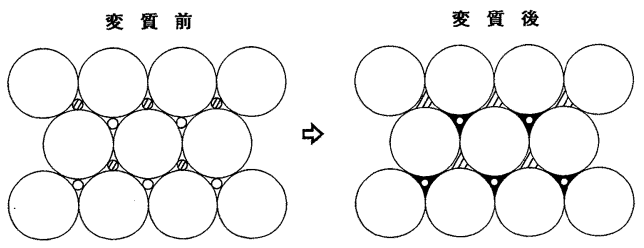

$$
\begin{gathered}
\text {; 坑道掘削ズリ } \\
\emptyset \text {; ベントナイト } \\
\text { O 炎山ガラス }
\end{gathered}
$$

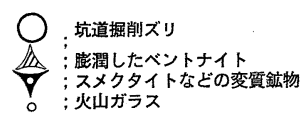

図-10 埋め戻し部における变質過程の概念図 


\section{3） 天然バリア}

火山ガラスを含む地層が天然バリアとなっている場 合, 人工地熱系にスメクタイトなどが生成され变質帯バ リアが形成される可能性がある。細倉鉱床では変質帯バ リアは透水性が良好な箇所で発達している。周辺より透 水性が良好なフラクチャーや緩み部に变質帯バリアが広 く生成されて透水性が低下する可能性がある。

\section{5. 処分場における変質帯バリア形成の意義}

\section{1 多重バリアシステムの補強}

半定量的に表現した多重バリアシステムの機能時間を 表-3に示す。高レベル放射性廃棄物は Cs - 137, S 90 等の半減期の短い核種を多量に含むため, 放射能レ ベルは初期に極めて高い。千年経過すると，放射能は約 数千分の 1 になる。高レベルの放射能が減衰した後に, 長期にわたって低レベルの放射能が残る8)。人工バリア には数千年の性能の維持が必要になり, 天然バリアには 数万年の安定性が要求される 50,51 。

$100^{\circ} \mathrm{C}$ での水熱反応実験19) から，火山ガラスは短時間 でスメクタイトに部分変質すると解釈される。また，活 地熱地域ではスメクタイトなどから成る変質帯バリアが 1 万 2 千年以内で形成されている実例がある。これらの ことから，人工地熱系の $100^{\circ} \mathrm{C}$ 以下の中性熱水環境下で は火山ガラスにスメクタイトなどが生成し，これらの変 質鉱物から成る变質帯バリアは 1 万年程度で形成され る可能性がある。この変質帯バリアの変質鉱物には低透 水性化・核種吸着の機能があり, 多重バリアシステムの 補強になることが期待される。

\section{2 ベントナイトの使用の減量}

現段階の計画では，処分坑道などの埋め戻し材や緩衝 材に大量のベントナイトが必要である。埋設後の変質作 用により 2 次的なスメクタイトが生成可能と考えられ, ベントナイトの節約が図られると考えられる。また，埋 め戻し材に坑道掘削ずりを利用できれば建設コストの削 減になると考えられる。

\section{3 火山ガラスを含有する天然バリアの評価}

処分場の周辺母岩である天然バリアが火山ガラスを含 有する場合にのみ，天然バリア中に変質帯バリアが形成 される可能性がある。火山ガラスを多く含む岩石として は, 火砕流堆積物・火砕岩, 泥岩が挙げられる。天然バ リアとして, 火山ガラスを含有する地層の評価も興味深 いと考えられる。

\section{6.おおりに}

細倉鉱床などの化石地熱系の熱水変質の研究は, 放射
表-3 多重バリアシステムの機能時間

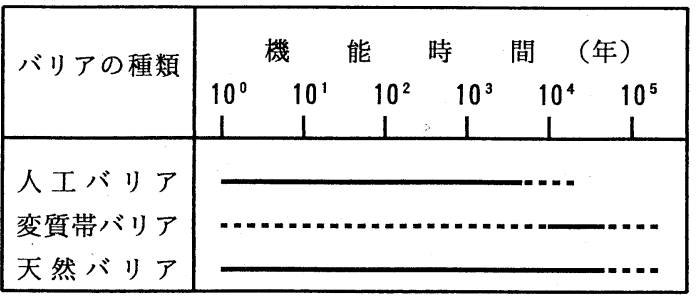

\section{——本格的な機能が期待される期間.}

......... 補助的な機能が期待される期間.

性廃棄物処分場のナチュラルアナログ研究に応用でき, 地層処分の計画・設計に役立つと考えられる。

人工地熱系で想定される50 100 ${ }^{\circ} \mathrm{C}$ 程度以下の中性熱 水環境下での変質作用で，火山ガラスにはスメクタイト ・ $\alpha$ クリストバライト・斜プチロル沸石・モルデン沸石 などの生成が予想される。これらの変質鉱物は低透水性 化・核種吸着の機能を有して抢り, 多重バリアシステム を補強する変質帯バリアを形成する可能性がある。

処分坑道などの埋め戻し材や緩衝材の主成分となるス メクタイトは変質作用による 2 次的な生成が可能と考 えられ，ベントナイトの節約になると考えられる。

本論文はまだ定性的な考察が多く, 定量的研究は今後 の課題としたい。

謝辞 大手開発(侏柏木高明社長，永松武彦調查本部 長からは論文発表の機会をいただいた。そのほかの関係 各位にも感謝の意を表す。

\section{参 考 文 献}

1）佐久間秀樹（1992）：高レベル放射性廃棄物と地層処分， 応用地質, Vol. 32, No. 6, pp. $272-280$.

2）高橋 洋 (1995)：変質帯キャップロックの形成機構一 細倉鉱床を実例として一，日本地熱学会誌，Vol. 17, No. 4 , pp. $271-284$.

3) WHITE, D. E., MUFFLER, L. J. P. and TRUESDELL A. H. (1971) : Vapor - dominated hydrothermal systems compared with hot - water systems. Econ. Geol., 6, 101 -120 .

4）高橋 洋 (1996)：地熱系の変質帯キャップロックの分 類, 日本地熱学会誌, Vol. 18, No. 1, pp. 1-15.

5）千木良雅弘（1995）：風化と崩壊一第 3 世代の応用地質 一, 近未来社, $204 \mathrm{p}$.

6）原啓二・五月女敦・藤田朝雄・棚井憲治・杉田 裕 （1992）：処分施設の技術開発，動然技報，No. 85, pp. $112-126$. 
7) 内藤守正・梅木博之 (1992) : 地層処分研究開発の考え方 と進め方, 動然技報, No. 85, pp. 10-13.

8）柴田雅博・佐々木康雄・佐藤治夫 · 龊谷朝紀 - 亀井玄人 ・三ツ井誠一郎（1992）：ベントナイトの化学的緩衝性お よび核種と相互作用に関する研究, 動然技報, No. 85, pp. $34-41$.

9）石川博久 ·柴田雅博 - 藤田朝雄 (1994) : 放射性廃棄物処 分に扔ける緩衝材のイライト化变質シミュレーション, 粘土科学, Vol. 34, No. 3, pp. 149-156.

10) HENLEY, R. W. and ELLIS, A. J. (1983) : Geothermal systems ancient and Modern: A geochemical review, Earth-Sci. Rev., Vol. 19, pp. 1-15.

11）島田寛一・藤野敏雄・古賀昭人・広渡和緒（1985）：八丁 原地熱地帯の酸性熱水の成因と対策, 地熱, Vol. 22, No. 4 , pp. $276-292$.

12）御生和則 - 清水 明（1992）：霧島地域白水越地区に存在 する酸性地熱流体, 日本地熱学会平成 4 年度学術講演会 講演要旨集 B1.

13）内藤守正 - 梅木博之 (1992) : シナリオ解析, 動然技報, No. 85 , pp. $14-22$.

14）通産省資源エネルギー庁（1976）：昭和50年度広域調查報 告書 (栗原地域), $38 \mathrm{p}$.

15）高橋 洋（1988）：細倉鉱床の鉱化変質分帯と生成モデ ル，鉱山地質，Vol. 38, No. 4, pp. 335-346.

16）青柳宏一（1979）：堆積岩中の自生鉱物を用いた古地温の 解析法, 石油技術協会誌, Vol. 44, No. 6, pp. 367-371.

17）森 康夫・陶山淳治（1980）: 地熱エネルギー読本, オー 么社, $92 p$.

18) HENLEY, R. W., TRUEDELL, A. H. and BARTON, P. B., Jr (1984) : Fulid - mineral eqilibria in hydorothermal systems, Reviews in Econ. Geol., Vol. 1, pp. 65-82.

19）河野元治・富田克利（1994）：低温水熱反応に上る黒曜石

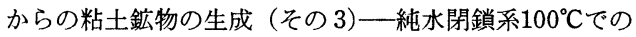
反応一，粘土科学, Vol. 34, No. 2, pp. 80-88.

20）歌田 実（1977）：鉱床母岩の变質作用, 現代鉱床学の基 礎（立見辰雄編），東京大学出版会，pp. 145-159.

21）鹿園直建・網川秀夫（1982）：細倉・佐渡鉱床の $\mathrm{K}-\mathrm{Ar}$ 年 代，鉱山地質，Vol. 32, pp. 479-482.

22）藤本光一郎（1987）: 部分的变質帯の幅を規制する要因, 鉱山地質, Vol. 37, No. 1, pp. 45-54.

23）土木学会編 (1979)：ダムの地質調査, pp. 91-96.

24）三箇智二・神原 洋-庄司敏行 - 岳山輝夫 (1992)：豊羽 鉱床に抢ける後期鉱化作用の特性と裂罅系, 資源地質, Vol. 42, No. 2, pp. $85-100$.

25）阿部一郎 - 鈴木英雄 - 磯上篤生 - 後藤寿幸 (1986) : 菱刈 鉱山の地質と探鉱開発, 鉱山地質, Vol. 36, No. 2, pp. $117-130$.

26）茨城謙三・鈴木良一 (1990)：菱刈鉱山鉱床母岩の熱水变 質について，鉱山地質，Vol. 37, No. 4, pp. 227-236.

27）安藤重幸（1983）: ボーリング結果からみた濁川カルデラ の構造, 月刊地球, Vol. 5, pp. 31-36.

28）黑墨秀行・土井宣夫（1993）: 濁川カルデラの内部構造, 日本火山学会予稿集1993年秋季大会 A14.

29）小松 亮 (1991)：北海道森地域の熱水変質について, 日 本地熱学会平成 3 年度学術講演会講演要旨集 A7.

30）高橋昌宏 - 池内 研 - 武田義則 - 伝法谷宜洋 (1992)：北
海道森地熱地域の観測井 $\mathrm{N} 2-\mathrm{KX}-3$ における熱水の坑 井内自然上昇流動, 第 2 回地下き裂のキャラクタリゼー ションワークショップ論文集, pp. $32-47$.

31）窪田康宏（1979）: 八幡平北部地区の地熱変質, 地熱, Vol. 16, No. 4, pp. 195-211.

32）䆶田康宏 - 谷下田雅之 - 番場光隆 - 加藤久遠 (1989)：大 沼－澄川地域における熱水対流系とそれに関連した变質 鉱物の分布, 日本地熱学会平成元年度学術講演会講演要 旨集 A11.

33）角 清愛 (1966)：岩手県松川地熱地帯における岩石の熱 水変質—その 1 ; 地表から深度 $400 \mathrm{~m}$ までの变質一, 鉱 山地質, Vol. 16, pp. 261-271.

34）金原啓司（1983）：八幡平東部地域における地熱変質帯と 地熱系, 岩鉱, Vol. 78, pp. 479-490.

35）高島 勲 (1988): 鬼首地熱地域の变質と熱水系, 地質調 查所報, Vol. 286 , pp. $229-244$.

36）新田富也・寿賀祥五・塚越重明・安達正畧（1987）：福島 県奥会津地域の地熱資源について，地熱，Vol. 24, No. 4, pp. $340-370$.

37) SEKI, Y. (1991) : The physical and chemical stractur of the Oku-aizu geothermal system, Japan. Geochem. J., Vol. 25 , pp. $245-265$.

38）林 二郎·本松利郎 - 近藤 充 (1988)：大分県滝上地区 の地熱資源について, 地熱, Vol. 25, No. 2, pp. 111-137.

39）真鍋 考・江島康彦 (1984)：八丁原地熱帯に抢ける裂か 型貯留層の地質構造特性および熱水系, 地熱, Vol. 21, No. 2, pp. $101-118$.

40）松本 正 (1989)：大岳・八丁原発電所の運転実績々貯留 層管理, 地熱, Vol. 26, No. 4, pp. 239-261.

41）馬場敬之 - 川副聖規 - 末吉喜和 (1991) : 大岳 -八丁原地 域における坑井掘削について, 地熱, 28, 4, pp. 273-296.

42）览玉牧夫・中島 完 (1988): 霧島地域の地熱開発調査, 地熱, Vol. 25, No. 3, pp. 201-230.

43）青柳宏一・浅川 忠 (1977) : 継変作用下における炭化水 素の第一次移動, 石油技誌, Vol. 42, pp. 76-89.

44）星野一男（1981）: 圧密と流体移動, 堆積盈中の流体移動 (杉山隆二 - 池辺 稞 - 星野通平 - 柴崎達雄編集), 東海 大学出版会, pp. $65-77$.

45）原 啓二 - 五月女敦 - 藤田朝雄 - 本田 明 - 柴田雅博 竹内真司・茂呂吉司 (1992)：人工バリア技術の研究開 発, 動然技報, No. 85, pp. 96-111.

46）根岸敏雄（1981）:クリノプチロル沸石の脱水機構とそれ の石油探鉱への応用，石油技誌，Vol. 46, pp. 75-88.

47）伊藤雅和 (1994)：ベントナイト利用の現状と新展開, 粘 土科学, Vol. 33, No. 4, pp. 193-201.

48）床次正安 (1994)：高レベル放射性廃棄物と鉱物学, 鉱物 学雑誌, Vol. 23, No. 4, pp. 151-156.

49）土木学会編（1979）：ダムの地質調査, pp. 134-143.

50）中野啓二.小出 下（1991）: 高レベル放射性廃棄物地層 処分における天然バリアー性能評価システムについて, 地質ニュース，Vol. 439, pp. 19-29.

51）小出 乞 (1992): 放射性廃棄物と地層問題, 応用地質, Vol. 32, No. 6, pp. 281-288.

(1995年 8 月 7 日受付, 1996 年 5 月 8 日受理） 